\title{
Landscape context of plantation forests in the conservation of tropical mammals
}

\author{
Rodrigo Anzolin Begotti ${ }^{\mathrm{a}, \mathrm{c}, *}$, Eduardo dos Santos Pacífico ${ }^{\mathrm{b}}$, Silvio Frosini de Barros Ferraz ${ }^{\mathrm{c}}$, \\ Mauro Galetti ${ }^{\mathrm{a}}$ \\ ${ }^{a}$ Laboratório de Biologia da Conservação, Departamento de Ecologia - Universidade Estadual Paulista, UNESP, Rio Claro 13506-900, SP, Brazil \\ ${ }^{\mathrm{b}}$ Aliança da Terra, Goiânia, GO, Brazil \\ ${ }^{\mathrm{c}}$ Laboratório de Hidrologia Florestal, Departamento de Ciências Florestais - Escola Superior de Agricultura Luiz de Queiroz, Esalq/USP, Rio Claro, SP, Brazil
}

\section{A R T I C L E I N F O}

\section{Keywords:}

Plantation forest

Eucalyptus

Pinus

Atlantic forest

Habitat fragmentation

Wildlife-friendly

\begin{abstract}
A B S T R A C T
Plantation forests have been expanding in many tropical and subtropical environments. Howerver, even when they replace less wildlife friendly land uses such as pastures and annual crops, the biodiversity levels of pristine natural habitats often have not been recovered. Here we addressed how the landscape context of plantation forests located in South-eastern Brazil affects species richness and community resilience of medium and large size mammals. The area covered by native habitat fragments surrounding plantation forests is positively related to functional richness, including the presence of species more vulnerable to extinction in fragmented landscapes. In addition, the degree of aggregation of plantation forest stands is negatively related to more vulnerable species. No primates were recorded in our seven plantation forest sites (ranging from 272 to 24,921 ha), even when they were seen in native habitat fragments adjacent to commercial tree stands. Two invasive species (Sus scrofa and Lepus capensis) were recorded in four plantation forest sites. The impoverishment of fauna in plantation forests is due to two factors. First, plantation forests generally are structurally simplified habitats when compared to highly diverse tropical forests. Secondly, the isolation from habitat fragments which act as source of individuals in the landscape precludes the establishment of individual in plantation forest. We also highlighted the management practices to improve the complexity of vegetation in commercial tree stands should be taken cautiously, insofar as reduced productivity per area entails a greater demand for land. Thus, an alternative would be intensify the management of the commercial tree stands for wood production together with the restoration of adjacent areas set aside to conservation and native habitat fragments protection.
\end{abstract}

\section{Introduction}

The conversion of natural environments and land use intensification in human-dominated landscapes has led to striking changes in the Earth's surface (Foley et al., 2005), resulting in an unprecedented global species loss and an increasing number of threatened species (Barnosky et al., 2011; Hoffmann et al., 2010; Pimm et al., 2014). Within this context, further loss in biodiversity and ecosystems services could be reduced through the suitable management of landscapes which have undergone anthropogenic changes (Gardner et al., 2009). However, the development and adoption of new practices of landscape management is a complex task, so that in recent years it has taken the shape of debate about land-sharing and land-sparing management strategies (Fischer et al., 2014). Landscape management should consider the population fluctuations of each species (Vandermeer \& Carvajal, 2001), the species-specific responses to the structure and configuration of the landscape (Lindenmayer, Cunningham, Donnelly, \& Lesslie, 2002; Tscharntke et al., 2012) and their resilience to habitat changes (Ewers \& Didham, 2006; Umetsu, Metzger, \& Pardini, 2008). Hence, the landscape context, i.e. how both structure and configuration of habitat fragments modulate the interaction of the species with surrounding human land-uses, is an important focus of ecological research in human-dominated landscapes to understand the driving forces of persistence or local extinction (Daily, Ceballos, Pacheco, Suzán, \& Sánchez-Azofeifa, 2003; Fischer, Lindenmayer, \& Manning, 2006; Lindenmayer et al., 2008).

Among the several human land-uses, the functional role of plantation forests as it relates to biodiversity conservation has also been vigorously debated (Brockerhoff, Jactel, Parrotta, Quine, \& Sayer, 2008). Plantation forests are expanding worldwide as result of an increasing demand for timber and pulp, and already represent about 7.3\% of the world's forest cover (FAO, 2015). In Brazil, the area planted with

\footnotetext{
* Corresponding author at: Division of Image Processing, National Institute for Space Research (INPE), São José dos Campos, 12227-010, Brazil.

E-mail address: rodrigo_anz@yahoo.com.br (R.A. Begotti).
} 


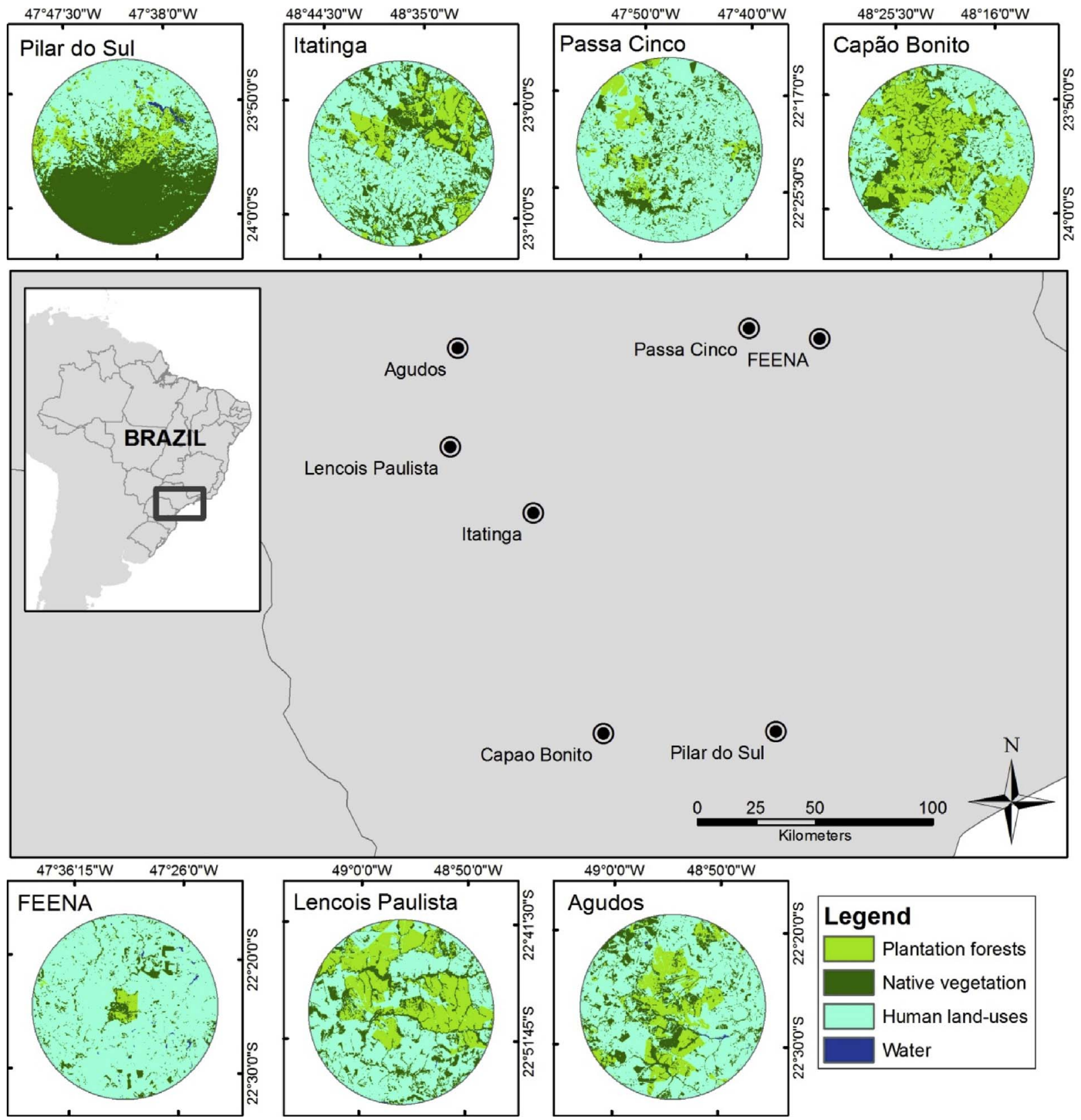

Fig. 1. Location of the seven plantation forests sites in São Paulo State, southeastern Brazil.

exotic Eucalyptus and Pinus trees reached more than 6.6 million hectares in 2012 ( $\sim 2.5 \%$ of country's territory), and only in the São Paulo state, forest plantations covered about $1,186,497$ ha or $17.8 \%$ of state's territory (ABRAF, 2013).

Although management practices for conservation of biodiversity differ widely depending on target-species, the role of plantation forests could be effectively complementary to protected areas and large tracts of pristine habitats (Barlow, Gardner, et al., 2007; Brockerhoff, Jactel, Parrota, \& Ferraz, 2013). Usually, plantation forests seem to hold a subset of the species assemblage found in undisturbed native habitats, even where the latter is the dominant land cover in the landscape (Barlow, Gardner, et al., 2007; Lindenmayer \& Hobbs, 2004). On the other hand, plantation forests can improve connectivity between habitat patches and provide a sub-optimal habitat for the biota in highly fragmented landscapes (Brockerhoff et al., 2008; Hartley, 2002). Thus, plantation forests could play a substantial role in biodiversity conservation if their management reduces the detrimental effects of habitat loss and fragmentation in both local and landscape scales (Brockerhoff et al., 2013).

The negative effects of habitat fragmentation are observed at multiple spatial scales. Changes in the structure and configuration of landscapes surrounding fragments affect the persistence of several taxa such as birds, mammals and others (Andrén, 1994; Mazerolle \& Villard, 1999). In studies at the fragment scale, the best predictors of changes in patterns of species abundance are given by inter-patch variables, such as Fragment Size and Edge Area, whereas landscape-scale variables such as Isolation are better predictors of species occurrence (Thornton, Branch, \& Sunquist, 2011). Thus, the occurrence of species in plantation forests could be an effect of landscape context, particularly, the distribution of native habitat patches and plantation stands in a given landscape.

The effectiveness of plantation forests for biodiversity conservation has been poorly studied when considering the influence of landscape attributes surrounding the commercial tree stands and vice versa. This 
is particularly true for Atlantic forest domain in Brazil, where only about $12 \%$ of the original forest cover remains (Ribeiro, Metzger, Martensen, Ponzoni, \& Hirota, 2009). The research effort has been focused almost exclusively in the comparison of species richness and assemblage composition found in native habitats and commercial trees stands. These studies have demonstrated the negative consequences of habitat simplification from commercial tree monocultures in relation to high diverse native tropical forest for birds (Marsden, Whiffin, \& Galetti, 2001; Volpato, Prado, \& dos Anjos, 2010; Zurita, Rey, Varela, Villagra, \& Bellocq, 2006), mammals (Dotta \& Verdade, 2011; LyraJorge, Ciocheti, \& Pivello, 2008; Martin, Gheler-Costa, Lopes, Rosalino, \& Verdade, 2012; Stallings, 1991), spiders (Baldissera, Ganade, Brescovit, \& Hartz, 2008), ants (Suguituru, Silva, Souza, Munhae, \& Morini, 2011), beetles (Puker, Ad'Vincula, Korasaki, Ferreira, \& Orozco, 2014), epiphytes (Boelter, Zartman, \& Fonseca, 2011) and leaf litter taxa (Rocha et al., 2013). The impoverishment or even the absence of understory is crucial to loss of biodiversity in plantation forests. However, there are also "external" factors such as the absence of native habitat fragments near to the commercial tree stands which would be a source of individuals in the landscape using plantation forests as corridors or even to find food and shelter. In this paper, we addressed how both structure and configuration of the landscape affect species richness and community resilience of medium and large-bodied mammal species in plantation forests in southeastern Brazil. Our study aims to assess (1) which landscape attributes determine species richness and the persistence of mammals, and (2) what is the role of plantation forests for the conservation of mammals, mainly those species which are prone to local extinction due to habitat fragmentation.

\section{Material and methods}

\subsection{Study sites}

Our dataset combines our field data with data obtained in the literature (Dotta \& Verdade, 2011; Mendonça, 2009; Silva, 2001; Silveira, 2005; Spínola, 2008). Field surveys were carried out in seven different plantation forest sites located in São Paulo State, Brazil (Fig. 1). We choose these sites because the field sampling was comprehensive and because they showed variability in the landscape structure surrounding the plantation forest sites. The size of plantation forest sites where the field surveys were carried out (not necessarily the area effectively surveyed) ranged from 88.99 ha (Passa Cinco) to 25,658 ha (Capão Bonito) with an average size of $9985 \pm 10,660$ ha (Table 1). The sites are between 30 and $205 \mathrm{~km}$ away of each other (Average Distance $=136 \mathrm{~km}$ ).

In five of the sites, there were stands planted with Eucalyptus spp., Corymbia spp. and Pinus spp. tree species, whereas two of them (Pilar do Sul and Passa Cinco) had only Eucalyptus spp. and Corymbia spp stands. Although the commercial pool of species differed from one site to another, comparison of such local effects was beyond the scope of this paper. Natural vegetation surrounding these sites included Tropical Semideciduous forests, as well as ecotone transition to Cerrado and Dense Evergreen forest, the latter the typical vegetation found in Pilar do Sul site. The native vegetation cover was adjacent to plantation forests stands and/or interspersed between them. Within a $15 \mathrm{~km}$ radius from the center of them, Pilar do Sul had the highest percentage of native forest cover (49.2\%) whereas the Floresta Estadual Edmundo Navarro de Andrade (hereafter FEENA) the lowest (8.2\%; Table 1). Surroundings of FEENA also, had the smallest percentage of plantation forest cover (1.7\%) and Capão Bonito had the highest (33.1\%).

\subsection{Data collection}

Our field sampling at FEENA involved $98.3 \mathrm{~km}$ of census walked along three transects (3.5-5 km in length), following protocol described by Peres, Barlow and Haugaasen (2003), and $99.7 \mathrm{~km}$ of intensive

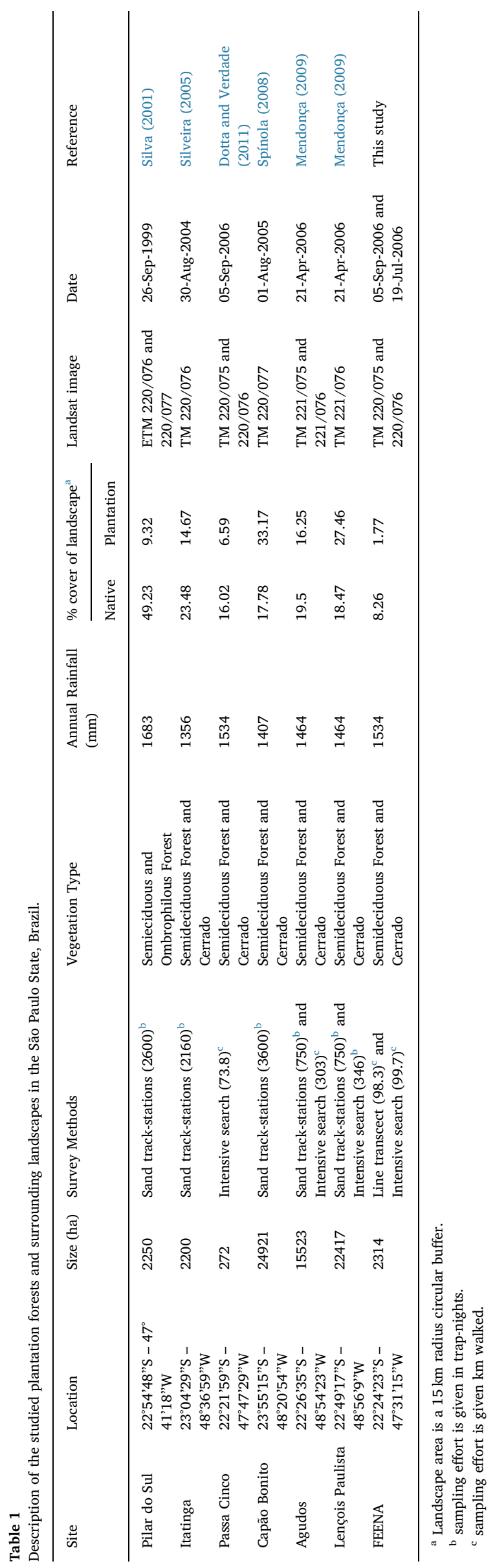


searches for tracks along trails and firebreaks. All walks were conducted at $1.7 \mathrm{~km} / \mathrm{h}$ average speed from $6: 00-10: 00 \mathrm{~h}$ and $14: 00-18: 00 \mathrm{~h}$ on days without rain between December 2005 and June 2007. Total sampling effort was $198 \mathrm{~km}$ resulting in 62 animal records (only two sightings). In the dataset compiled from literature review, the sampling protocols adopted used sand track-stations, intensive search for tracks, occasional records or a combination of these methods (Table 1). Sampling effort in all these areas was conducted for at least 6 months during a year and covered both plantation forest stands and adjacent native vegetation patches. In Table 1, we described the sampling effort carried out in plantation forest only. In three sites where sand track-stations was the main used method, the effort ranged from 2160 to 3600 trapnights. When the main protocol for field sampling was the intensive search for tracks, the distance walked ranged from 73.8 to $346 \mathrm{~km}$ (Table 1).

We built a presence-absence matrix from data of species found in plantation forests stands or those seen in firebreaks and dirt roads between native vegetation and plantation stands, including small mammal species ( $>1 \mathrm{~kg}$; Guerlinguetus aestuans and Cavia aperea; Appendix A). For some species with uncertain identification, we grouped data at genus level (Didelphis, Leopardus, excluding L. pardalis, Mazama, Guerlinguetus and Cavia). Because of unreliable identification of porcupines at species level (Coendou spp. and Sphigurus spp. have nocturnal and arboreal habits), we excluded these data from the analysis. All species of our matrix have wide geographical distribution and are readily detected by the adopted sampling protocols. Thus, this allows us to compare the fauna in different plantation forest sites even when different sampling protocols and effort were carried out. We also gathered information on invasive species such as wild boar (Sus scrofa) and cape hare (Lepus capensis) that were recorded in some of the plantation forest sites (Appendix A). Therefore, our database consisted of 26 mammalian species and four genera as functional groups, providing a total of 30 taxa analyzed.

\subsection{Functional diversity as a proxy of vulnerability to extinction}

Human-induced changes in natural environments such as habitat loss, fragmentation and matrix roughness (i.e. how difficult it is to move across the landscape) affect species differently (Díaz et al., 2013; Tscharntke et al., 2012). Different responses to changes in the habitat have been related to some species-specific functional traits (Blaum, Mosner, Schwager, \& Jeltsch, 2011; Hooper et al., 2005). According to Flynn et al. (2009), functional traits are measurable features of a given organism concerning its interaction with habitat and other organisms such as resources use, body growth rates, reproduction and survival. Certain functional traits are good indicators of species vulnerability to extinction in fragmented landscapes as they represent the ability of species to survive in modified habitats such as plantation forests.

In order to ensure that suitable functional traits were chosen, we review the literature of the main traits related to vulnerability of species to extinction and response to habitat changes (Table 2). Our proxy of species-specific vulnerability to extinction was based on nine functional traits provided by Pereira and Daily (2006) adapted for South American species. We added to this dataset the species feeding habitats and locomotion habitat categories provided by Paglia et al. (2012). Data on invasive species were removed from analysis of functional traits. We applied the Functional Diversity Indices (FD) proposed by Mason, Mouillot, Lee, and Wilson, 2005 and Villéger, Mason, and Mouillot, 2008 to represent the relative space and distribution of vulnerability to extinction of mammals present in plantation forests. We used the package FD (Laliberté \& Legendre, 2010) available to R statistical environment version 3.1.2 (R Development Core Team, 2014) for the calculation of functional richness (FRic), functional evenness (FEve) and functional divergence (FDiv). In addition, we adjusted non-Euclidean portion of distance matrix using Cailliez correction eliminating negative eigenvalues (Legendre \& Anderson, 1999).
The Functional Diversity Indices are suitable even when they are calculated from presence-absence data (Villéger et al., 2008). By definition, functional richness represents the amount of functional space occupied by community, functional evenness corresponds to the regularity of relative positioning of each species in the functional space and functional divergence represents the distance them from the center of functional space (Mouchet, Villéger, Mason, \& Mouillot, 2010; Villéger et al., 2008). For our purposes, functional space could be designated as the range of species vulnerability to extinction in human modified landscapes. Thus, in functionally richer plantation forests, species vulnerability would be more variable. Plantation forests where functional evenness is high, the number and degree of vulnerable species would be equivalent to non-vulnerable species. In functionally divergent plantation forests, the degree of vulnerability between species would be more contrasting.

\subsection{Landscape structure}

We assessed the landscape structure adjacent to study sites using images of Landsat 5 Thematic Mapper and Landsat 7 Enhanced Thematic Mapper (30 $\mathrm{m}$ spatial resolution), acquired from the Brazilian National Spatial Research Institute (INPE; http://www.dgi.inpe.br/ CDSR). We selected images obtained at the time corresponding to the field sampling of each study site (Table 1). In addition, when present, the area covered by clouds in these images was not large enough to preclude or compromise the quality of land cover classification.

We carried out the geometric correction of stacked non-thermal bands using the Third Order Polynomial algorithm and resampling method of Nearest Neighbor, available in software Erdas version 9.1 (Leica Geosystems, 2006). By mean of geometric correction, we generated at least 250 control points per image from reference Landsat images acquired from Global Land Cover Facility (http://glcfapp.glcf. umd.edu; acessed in 10 December of 2014), projected in UTM and Datum WGS-1984 zones 22 or $23 \mathrm{~S}$. The global mean of RMS error for the geometric correction was $0.3161 \pm 0.056$ pixel.

We set a circular buffer with $15 \mathrm{~km}$ radius from the center of the plantation forest site surveyed. We adopted this arbitrary size to properly include in our analysis of landscape context, the whole area of these plantation forests and their surroundings. In order to perform the land-cover classification, we use the supervised method by mean of Maximum Likelihood algorithm only with the combination of bands 3, 4 and 5 . We identified the major land cover classes present in the seven study landscapes previously to the classification procedure by collecting a minimum of 15 samples of spectral signatures for each of them. Thus, we produced maps classified as following: i) water; ii) natural habitats (forests and savanna "Cerrado" vegetation); iii) forest plantation (Eucalyptus and Pinus stands); iv) citrus plantation; and v) annual crops, pastures, urban areas and others uses, gathered as matrix. In order to improve the classification accuracy, we corrected misclassified areas based on high resolution images available in Google Earth ${ }^{\circledR}$ platform, recoding manually the misclassified pixels. We merged the land-cover classes citrus plantation and matrix for the completion of classified maps.

We calculated a suite of landscape metrics using Fragstats 4.2 (McGarigal, Cushman, \& Enen, 2012) aiming to assess at how mammals respond to changes in the structure, spatial distribution and distance between native habitat patches and plantation forests stands. We used the suffix "nat" to designate the metrics related to the native habitat class and "euc" for plantation forest class. For each landscape, we calculated the percentage of area covered by each class (PLAND), the Fractal Dimension index (FRAC_MN) for quantifying the shape complexity of patches, Clumpiness index (CLUMPY), which represents the degree of aggregation of patches of same class based on pixel adjacencies and mean Euclidean Nearest Neighbor distance (ENN_MN). Moreover, we calculated the Interspersion and Juxtaposition index (IJI) at landscape level. IJI measures how immersed are patches of a given 
Table 2

Functional traits for each mammalian species and functional importance to their survival in anthropogenic habitats.

\begin{tabular}{|c|c|c|}
\hline Functional trait & Functional importance & References \\
\hline Mean Body Size (g) & $\begin{array}{l}\text { Larger bodied mammals are more susceptible to hunting and } \\
\text { persecution. They also, have usually lower reproductive rate. }\end{array}$ & $\begin{array}{l}\text { Purvis, Agapow, Gittleman, and Mace, 2000; Cardillo et al. } \\
\text { (2005), Cardillo, Mace, Gittleman, \& Purvis, } 2006\end{array}$ \\
\hline Litter size & $\begin{array}{l}\text { Species with small litters are less able to compensate for increased } \\
\text { mortality. }\end{array}$ & $\begin{array}{l}\text { Purvis, Agapow, et al. (2000); Cardillo (2003); Cardillo } \\
\text { et al. (2006) }\end{array}$ \\
\hline Litter interval & Longer litter interval is associated with lower reproductive rates. & $\begin{array}{l}\text { Harcourt and Schwartz (2001); Jones, Purvis, and } \\
\text { Gittleman, } 2003\end{array}$ \\
\hline Breeding age (year) & $\begin{array}{l}\text { Species with later sexual maturity are associated with lower } \\
\text { reproductive rates. }\end{array}$ & $\begin{array}{l}\text { Purvis, Gittleman, Cowlishaw, and Mace, 2000; Cardillo } \\
\text { et al. (2006), } 2008\end{array}$ \\
\hline Mean lifespan (year) & $\begin{array}{l}\text { Longevity in mammals is inversely associated with potential } \\
\text { reproductive rates. }\end{array}$ & Holliday (2005) \\
\hline $\begin{array}{l}\text { Estimated population growth rate in the native } \\
\text { habitat (individuals/year) }\end{array}$ & $\begin{array}{l}\text { Population growth rate mediates the extinction risk against } \\
\text { environmental stochasticity and random catastrophes. }\end{array}$ & (Lande, 1993), Pereira and Daily (2006) \\
\hline Critical patch diameter $(\mathrm{km})$ & $\begin{array}{l}\text { This is a measure of vulnerability to land use change whereby } \\
\text { species with higher values require large home ranges. }\end{array}$ & Brashares (2003); Pereira and Daily (2006) \\
\hline Feeding guild & $\begin{array}{l}\text { The specific use of food resources is related to sensitivity to habitat } \\
\text { fragmentation. }\end{array}$ & $\begin{array}{l}\text { Vetter, Hansbauer, Végvári, and Storch, 2011; Blaum et al. } \\
\text { (2011) }\end{array}$ \\
\hline Foraging habit & $\begin{array}{l}\text { The foraging habit represents the strategies and specific use of the } \\
\text { habitat. }\end{array}$ & Blaum et al. (2011) \\
\hline
\end{tabular}

land-cover class between patches of other land-cover class present in that landscape. It ranges from 0 , when the distribution of adjacencies of a given class tend to be uneven in regard to the other land-cover classes to 100 , when all patches of all land-cover classes are equally adjacent.

\subsection{Statistical analysis}

In order to evaluate how the landscape context of plantations forests sites affects the species richness and functional diversity, we used redundancy analysis (RDA; Ter Braak \& Prentice, 1988; Ter Braak 1994) having the landscape metrics as our explanatory variables. The first step of RDA is regress each response variable on all variables of the matrix of explanatory variables, and next, carry out a Principal Component Analysis from the matrix of fitted values generated by the regression obtaining eigenvalues and eigenvectors (Legendre \& Legendre, 1998). We used the R environment (R Development Core Team, 2014) for all statistical analysis. First, we made a correlation matrix to verify the presence of correlation between the explanatory variables $(r>0.75)$. We found high correlation between ENN_MNnat and IJI, CLUMPYnat and both CLUMPYeuc and PLANDnat, FRAC_MNeuc and PLANDeuc, and $E N N_{-} M N e u c$ and IJI. Thereby, we opted to remove the variables $E N$ N_MNnat, CLUMPYnat, FRAC_MNeuc and ENN_MNeuc from the analysis. Thus, to perform the redundancy analysis we used four response variables and five explanatory variables (Appendix B). Likewise in a regression analysis, RDA calculates a $R^{2}$ that explains the proportion of variation of response matrix by explanatory matrix. However, because the $R^{2}$ of RDA is biased, we also calculated the adjusted $R^{2}$ to evaluate the performance of explanatory variables (Peres-Neto, Legendre, Dray, \& Borcard, 2006). Due to the potential influence of covariates, we controlled for the effects of collinearity by calculating the variance inflation factor of regression coefficients (Dormann et al., 2013). Moreover, we tested whether the relationship between the explanatory and response matrices (i.e. the global model), are different from random using a Monte Carlo test with 1000 permutations (Legendre, Oksanen, \& ter Braak, 2011). We also tested the significance of relationships between canonical axes, and as well as of each explanatory variables.

\section{Results}

Seven of 30 species/functional groups were recorded in all sites, among them, habitat generalists such as nine-banded armadillo (Dasypus novemcinctus), crab-eating fox (Cerdocyon thous) and crabeating raccoon (Procyon cancrivorus), large carnivores (puma; Puma concolor) and game species (brocket's deers Mazama spp.; see Appendix
A). Other native ungulate species were less common. Collared peccary (Pecari tajacu) in turn, were recorded in four areas, whereas lowland tapir (Tapirus terrestris) was found only in two sites (Pilar do Sul and Capão Bonito). There were no records of primate or white-lipped peccary (Tayassu pecari) in all of seven plantation forest sites sampled. The invasive species were recorded in four plantation forest sites (Itatinga, Passa Cinco, Agudos and FEENA). L. capensis was recorded in four areas whereas $S$. scrofa was recorded in Passa Cinco and FEENA, the two sites with the lower proportion of landscapes covered by native vegetation.

The first two RDA axes explained $92.6 \%$ of variance of fitted data (58.8 and $33.7 \%$, respectively). There was little difference between RDA $R^{2}(0.987)$ and the adjusted RDA $R^{2}(0.924)$, indicating that the strong relationship between explanatory and response matrix found was properly estimated. The test of significance for the global model with 1000 permutations corroborated this result $\left(F_{3.94}=15.648\right.$, $d f=5, p=0.028)$, as well as the test for the first canonical axis $\left(F_{2.35}=93.302, d f=1, p=0.021\right)$ and the second one $\left(F_{1.35}=53.522\right.$, $d f=1, p=0.019$ ). Similarly, the test for each explanatory variables showed highly significant results for PLANDnat and CLUMPYeuc (Table 3). The regression coefficients did not exhibit the influence of covariates indicating the absence of collinearity between our explanatory variables, once all variance inflation factors were less than 10 (Dormann et al. 2013; Table 3).

The explanatory variables that showed significant relationships with matrix of response variables had opposite results (Fig. 2). The proportion of landscape covered by native habitats (PLANDnat) was positively correlated with functional richness (FRic), whereas the degree of aggregation of commercial tree stands (CLUMPYeuc) was negatively correlated with FRic. Indeed, more native vegetation in the landscape and less aggregation of plantation forests stands contribute positively to the

Table 3

Significance test of explanatory variables constrained on the RDA axes and the variance inflation factors (VIF) to control the collinearity.

\begin{tabular}{lllll}
\hline Explanatory variable & Variance & F value & $p$ & VIF \\
\hline PLANDnat & 1.5418 & 30.54 & 0.008 & 7.795 \\
FRAC_MNnat & 0.4691 & 9.293 & 0.042 & 3.253 \\
PLANDeuc & 0.5498 & 10.89 & 0.035 & 8.162 \\
CLUMPYeuc & 1.1417 & 22.61 & 0.018 & 4.538 \\
IJI & 0.2470 & 4.894 & 0.115 & 6.835
\end{tabular}

$P L A N D=$ Proportion of landscape; FRAC_MN = Fractal Dimension index; CLUMPY $=$ Clumpiness index; $I J I=$ Interpersion and Juxtaposition index. 


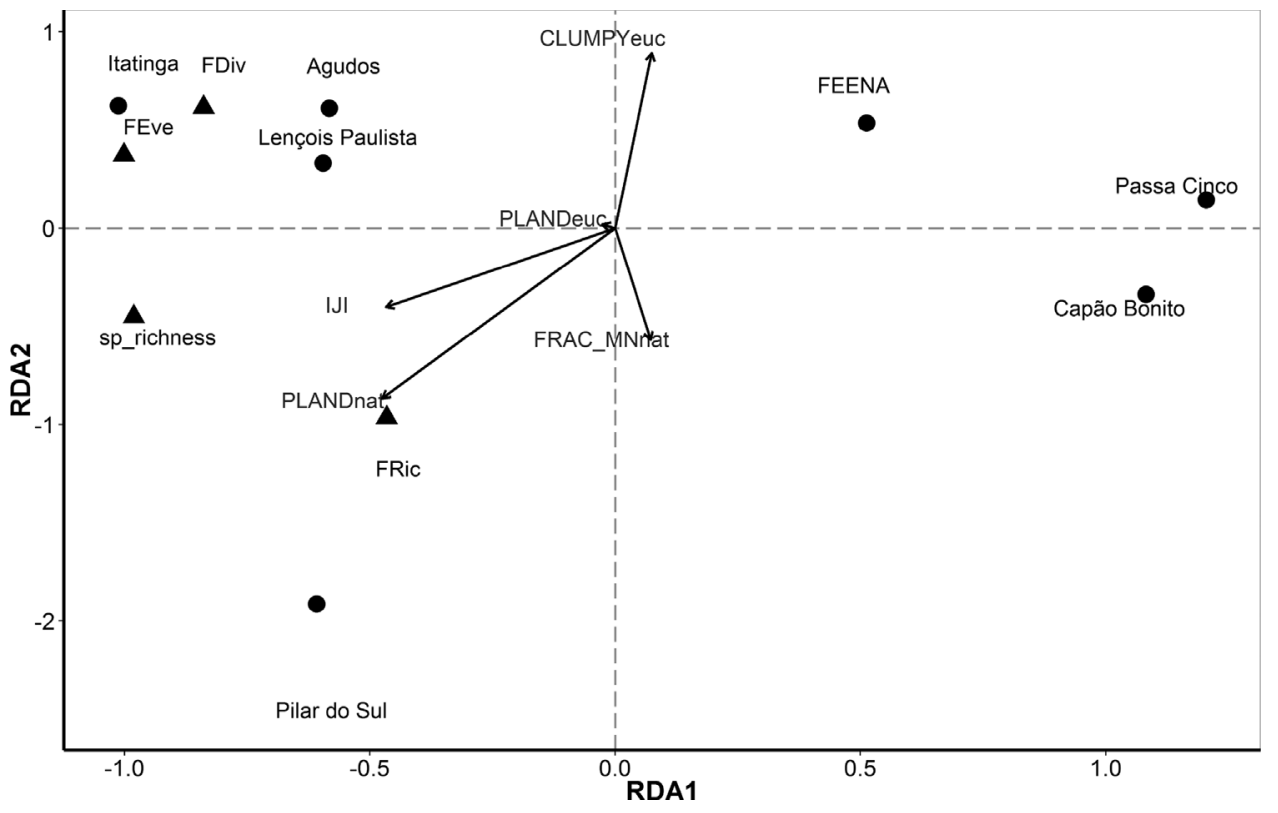

Fig. 2. RDA triplot of correlations of variables and plantation forest sites constrained by landscape metrics eigenvalues. Circles indicate the seven plantation forest sites, and triangles and arrows represent response and explanatory variables, respectively. increasing of functional richness. On the other hand, species richness is not strongly correlated with PLANDnat, although the relationship tends to be positive. Functional Evenness (FEve) and Functional Divergence (FDiv) did not show any clear relationship with the significant explanatory variables.

\section{Discussion}

The effectiveness of plantation forests for conservation is strongly dependent on the landscape context, mainly regarding the structure and spatial distribution of native habitat fragments throughout the landscape. Our results suggest that the area of the landscape covered by natural habitats is critical to ensure that species more vulnerable to extinction can persist in the landscape and occur in plantation forest. Landscape context appears to be important not only in Eucalyptus and Pinus plantations. Alongside oil palm plantations in South-east Asia, the variation on species richness is strongly explained by total area of native habitats (Azhar, Lindenmayer, Wood, Fischer, \& Zakaria, 2014). Moreover, distance from oil palm plantations to native habitat fragments has strong negative relationship with species richness, where threatened species such as Malayan tigers, sun bears and Asiatic tapir were recorded only within $5 \mathrm{~km}$ of forest fragments (Azhar et al., 2014; Yue, Brodie, Zipkin, \& Bernard, 2015). In rubber plantations also, the distance and the area of native habitats in the landscape are positively related to overall bird species richness and forest dependent species (Zhang, Chang, \& Quan, 2017).

The combination of spatial aggregation of commercial trees stands and low cover of native habitats in the landscape might lead to impoverishment of the community of medium and large-bodied mammals found in plantation forests. In spite of the relationship between proportion of native vegetation cover and functional diversity, this study did not assess the conditions of those native habitat fragments, and this variable could be considered in further studies since native vegetation fragments usually present high variation of conditions resulting in different habitat quality (Ferraz et al., 2014). On the other hand, plantation forests managed by pulp and fiber industries keep adjacent areas for conservation with native vegetation, as requirements of the Brazilian Forest Code and forestry management certification (Brockerhoff et al., 2013). These set aside areas can improve the conservation value of plantation forests, once commercial tree stands only has a limited role in biodiversity conservation because the mammalian fauna found there is often similar to or more impoverished than that found in small and isolated fragments of Atlantic forest (Beca et al., 2017; Canale, Peres, Guidorizzi, Gatto, \& Kierulff, 2012; Chiarello, 1999; Dotta \& Verdade, 2011).

In a literature review, Ramírez \& Simonetti (2011) found species richness and abundance of mammals in plantation forests were always lower than found in native forests. For example, tapirs were rare or even absent from plantation forests, whereas white-lipped peccaries were not found in any of the plantation forest sites studied here. These species are known to be more vulnerable to extinction due to habitat loss and fragmentation (Jorge, Galetti, Ribeiro, \& Ferraz, 2013) as well as hunting pressure (Cullen Jr. \& Bodmer, 2001). Thus, their presence in plantation forests could be strictly dependent on surrounding native habitat. Others studies have found the same pattern for multiple taxa comparing species richness between commercial tree stands and fragments of native vegetation. For example, the species richness of birds showed marked impoverishment in Eucalyptus and Pinus plantations (Barlow, Mestre,Barlow, Mestre, Gardner, \& Peres, 2007; Marsden et al., 2001; Volpato et al., 2010; Zurita et al., 2006), as well as small mammals (Martin et al., 2012), Cetoniinae beetles (Puker et al., 2014), lizards, myriapods, arachnids (Fonseca et al., 2009; Rocha et al. 2013), ants (Rocha et al., 2013; Suguituru et al., 2011), vascular epiphytes (Boelter et al., 2011; Fonseca et al., 2009), and fungi, galling insects, butterflies, and flatworms (Fonseca et al., 2009). However, when compared with other human land-uses, plantation forests definitely hold more species of medium and large mammals than pastures and annual crops. Even the plantation forest site with the lower species richness (Passa Cinco; $S=15$ ) hold more species than neighbor pastures $(S=10)$ and neighbor sugarcane crops $(S=13)$ (Dotta \& Verdade, 2011).

At the plantation forest scale, the impoverishment of mammal community, particularly of arboreal species, could be also attributed to larger canopy openness as well as changes in understory such as lower diversity, lower basal area (Barlow, Gardner, et al., 2007; Boelter et al., 2011; Zurita et al., 2006) and the lack of plants with fleshy fruits and epiphytes (Fonseca et al., 2009). The absence of primate species in all plantation forest sites studied is the most noticeable consequence of habitat simplification (Coelho, Juen, \& Mendes-Oliveira, 2014; Stallings, 1991). Primate groups were recorded in the forest fragments adjacent to commercial tree stands in Pilar do Sul, Agudos and Lençois Paulista (Mendonça, 2009, Silva, 2001). Groups of black-horned capuchin monkeys (Sapajus nigritus), brown howler monkeys (Alouatta guariba), black-pencilled marmosets (Callithrix penicillata) and even the 
endangered black-lion tamarins (Leontopithecus chrysopygus) were observed foraging in the border of fragments, but they were not seen crossing the firebreaks towards commercial tree stands. In contrast, capuchin monkeys were observed damaging trees of Pine stands in months of scarce availability of fruits in native habitat fragments in Southern Brazil (Mikich \& Liebsch, 2014). Moreover, flowers, seeds and nectar of the Eucalyptus trees were recorded as food items by bearded capuchin monkeys (Sapajus libidinosus; Freitas, Setz, Araújo, \& Gobbi, 2008).

Primate species are able to persist in the plantation forests but not exclusively on it and only under certain conditions. For example, howler monkeys groups living in Eucalyptus plantation with unmanaged understory had similar mean group size from those found in continuous forest (Bonilla-Sánchez, Serio-Silva, Pozo-Montuy, \& Chapman, 2012). Although, howler monkeys were often seen foraging in the understory, they spent the most of time feeding in adjacent native forest fragments (Bonilla-Sánchez, Serio-Silva, Pozo-Montuy, \& Chapman, 2012).

The presence of invasive species in the plantation forests sites reveals a major concern for conservation management, since wild boars and cape hares are spreading across the Brazilian territory (Auricchio \& Olmos, 1999; Pedrosa, Salerno, Padilha, \& Galetti, 2015). Moreover, the temporal range of field surveys synthesized here ( $~ 7$ years) may give an underestimation about the presence of invasive species on plantation forest sites. Although it requires corroboration, is plausible the hypothesis in which plantation forests located at highly fragmented landscapes suit as refuge for invasive such as wild boars and cape hares.

Usually, the trade-offs between land-sparing and land-sharing management have been applied for areas of food production (Fischer et al. 2014). In plantation forests, gains in biodiversity and profitable harvest would be better achieved with management intensification of commercial tree stands, protection and restoration of surrounding native habitats, and improvement of landscape connectivity. For example, logging operations in Borneo achieved higher levels of biodiversity whether they combine areas with high-intensity harvest and sparing areas without timber extraction (Edwards et al., 2014). This wildlifefriendly management finds legal support in the Brazilian forest code (Galetti et al., 2010) and should be reinforced by certification mechanisms (Brockerhoff et al., 2013). In terms of fulfillment of legislation and management certification, the pulp and fiber sector in Brazil is more willing to accomplish these requirements than others sectors of economy, such as soybean and cattle (Azevedo et al., 2017; Martinelli, Joly, Nobre, \& Sparovek, 2010).

These results highlight the importance of landscape context and the conservation value of small and isolated native habitat fragments for medium and large mammals. The value for conservation of plantation forests is necessarily linked with the conservation of native habitat fragments in their midst. In landscapes where natural habitats are highly reduced and fragmented, the importance of plantation forest cannot be depreciated. For those species that persist in these landscapes, plantation forests can facilitate movement and dispersion between fragments improving the permeability of landscape, mainly compared with open environments like pastures and annual croplands. In the case of the Brazilian Atlantic forest, more permeable landscape can be crucial for the viability of many populations of medium and large-bodied mammals.

\section{Acknowledgements}

We are thankful to our colleagues that helped us in the fieldwork, especially Carlos O. A. Gussoni. Instituto Nacional de Pesquisas Espaciais (INPE) provided the Landsat images and Instituto Florestal for the permission to carry out our field survey at FEENA. We also thank Mark Abrahams, Cathal O'Mahony and two anonymous reviewers who improved this paper with critical comments, Felipe Rosseti de Paula and Danielle Storck Tonon for the help with statistical analysis. RAB received fellowship from Conselho Nacional de Desenvolvimento
Científico e Tecnológico (PIBIC/CNPq/Unesp), ESP received a fellowship from Fundação de Amparo à Pesquisa do Estado de Goiás (FAPEG; Proc. \#201300377430172), and MG receives a research fellowship from Conselho Nacional de Desenvolvimento Científico e Tecnológico (CNPq).

\section{Appendix A. Supplementary data}

Supplementary material related to this article can be found, in the online version, at doi:https://doi.org/10.1016/j.jnc.2017.11.009

\section{References}

ABRAF (2013). Statistical yearbook 2013 - Base year 2012. http://www.ipef.br/estatisticas/relatorios/anuario-ABRAF13-EN.pdf. Acessed 10 December 2014.

Andrén, H. (1994). Effects of habitat fragmentation on birds and mammals in landscapes with different proportions of suitable habitat: A review. Oikos, 71(3), 355-366. http://dx.doi.org/10.2307/3545823.

Auricchio, P., \& Olmos, F. (1999). Northward range extension for the european hare, Lepus europaeus Pallas, 1778 (Lagomorpha-Leporidae) in Brazil. Publicacoes Avulsas Do Instituto Pau Brasil de Historia Natural, (2), 1-5 Retrieved from http://biblat.noip.org/revista/publicacoes-avulsas-do-instituto-pau-brasil-de-historia-natural/articulo/northward-range-extension-for-the-european-hare-lepus-europaeus-pallas1778-lagomorpha-leporidae-in-brazil.

Azevedo, A. A., Rajão, R., Costa, M. A., Stabile, M. C. C., Macedo, N. M., Reis, T. N. P., ,.. Pacheco, R. (2017). Limits of Brazil's forest code as a mean to end illegal deforestation. Proceedings of the National Academy of Sciences of the United States of America, 114(29), 7563-7658. http://dx.doi.org/10.1073/pnas.1604768114.

Azhar, B., Lindenmayer, D. B., Wood, J., Fischer, J., \& Zakaria, M. (2014). Ecological impacts of oil palm agriculture on forest mammals in plantation states and smallholdings. Biodiversity and Conservation, 23, 1175-1191. http://dx.doi.org/10.1007/ s10531-014-0656-z.

Baldissera, R., Ganade, G., Brescovit, A. D., \& Hartz, S. M. (2008). Landscape mosaic of Araucaria forest and forest monocultures influencing understorey spider assemblages in southern Brazil. Austral Ecology, 33(1), 45-54. http://dx.doi.org/10.1111/j.14429993.2007.01789.x.

Barlow, J., Gardner, T. A., Araujo, I. S., Ávila-Pires, T. C., Bonaldo, A. B., Costa, J. E., ... Peres, C. A. (2007). Quantifying the biodiversity value of tropical primary, secondary, and plantation forests. Proceedings of the National Academy of Sciences of the United States of America, 104(47), 18555-18560. http://dx.doi.org/10.1073/pnas. 0703333104.

Barlow, J., Mestre, L. A. M., Gardner, T. A., \& Peres, C. A. (2007). The value of primary, secondary and plantation forests for Amazonian birds. Biological Conservation, 136(2), 212-231. http://dx.doi.org/10.1016/j.biocon.2006.11.021.

Barnosky, A. D., Matzke, N., Tomiya, S., Wogan, G. O. U., Swartz, B., Quental, T. B., ... Ferrer, E. A. (2011). Has the Earth's sixth mass extinction already arrived? Nature, 471(7336), 51-57. http://dx.doi.org/10.1038/nature09678.

Beca, G., Vancine, M. H., Carvalho, C. S., Pedrosa, F., Alves, R. S. C., Buscariol, D., ... Galetti, M. (2017). High mammal species turnover in forest patches immersed in biofuel plantations. Biological Conservation, 210, 352-359. http://dx.doi.org/10. 1016/j.biocon.2017.02.033.

Blaum, N., Mosner, E., Schwager, M., \& Jeltsch, F. (2011). How functional is functional? Ecological groupings in terrestrial animal ecology: Towards an animal functional type approach. Biodiversity and Conservation, 20(11), 2333-2345. http://dx.doi.org/10. 1007/s10531-011-9995-1.

Boelter, C. R., Zartman, C. E., \& Fonseca, C. R. (2011). Exotic tree monocultures play a limited role in the conservation of Atlantic forest epiphytes. Biodiversity and Conservation, 20(6), 1255-1272. http://dx.doi.org/10.1007/s10531-011-0026-z.

Bonilla-Sánchez, Y. M., Serio-Silva, J. C., Pozo-Montuy, G., \& Chapman, C.a. (2012) Howlers are able to survive in eucalyptus plantations where remnant and regenerating vegetation is available. International Journal of Primatology, 33(1), 233-245. http://dx.doi.org/10.1007/s10764-011-9569-9.

Brashares, J. S. (2003). Ecological, behavioral, and life-history correlates of mammal extinctions in West Africa. Conservation Biology, 17(3), 733-743. http://dx.doi.org/ 10.1046/j.1523-1739.2003.01592.x.

Brockerhoff, E. G., Jactel, H., Parrotta, J. A., Quine, C. P., \& Sayer, J. (2008). Plantation forests and biodiversity: Oxymoron or opportunity? Biodiversity and Conservation, 17(5), 925-951. http://dx.doi.org/10.1007/s10531-008-9380-x.

Brockerhoff, E. G., Jactel, H., Parrota, J. A., \& Ferraz, S. F. B. (2013). Role of eucalypt and other planted forests in biodiversity conservation and provision of biodiversity-related ecosystem services. Forest Ecology and Management, 301, 43-50. http://dx.doi. org/10.1016/j.foreco.2012.09.018.

Canale, G. R., Peres, C. A., Guidorizzi, C. E., Gatto, C. A. F., \& Kierulff, M. C. M. (2012). Pervasive defaunation of forest remnants in a tropical biodiversity hotspot. PLoS One, 7(8), http://dx.doi.org/10.1371/journal.pone.0041671.

Cardillo, M. (2003). Biological determinants of extinction risk: Why are smaller species less vulnerable? Animal Conservation, 6(1), 63-69. http://dx.doi.org/10.1017/ S1367943003003093.

Cardillo, M., Mace, G. M., Gittleman, J. L., Jones, K. E., Bielby, J., \& Purvis, A. (2008). The predictability of extinction: Biological and external correlates of decline in mammals. Proceedings. Biological Sciences/The Royal Society, 275(1641), 1441-1448. http://dx. doi.org/10.1098/rspb.2008.0179. 
Cardillo, M., Mace, G. M., Gittleman, J. L., \& Purvis, A. (2006). Latent extinction risk and the future battlegrounds of mammal conservation. Proceedings of the National Academy of Sciences of the United States of America, 103(11), 4157-4161. http://dx. doi.org/10.1073/pnas.0510541103.

Cardillo, M., Mace, G. M., Jones, K. E., Bielby, J., Bininda-Emonds, O. R. P., Sechrest, W., .. Purvis, A. (2005). Multiple causes of high extinction risk in large mammal species. Science (New York, N.Y.), 309(5738), 1239-1241. http://dx.doi.org/10.1126/ science. 1116030 .

Chiarello, A. G. (1999). Effects of fragmentation of the Atlantic forest on mammal communities in south-eastern Brazil. Biological Conservation, 89(1), 71-82. http://dx.doi. org/10.1016/S0006-3207(98)00130-X.

Coelho, M., Juen, L., \& Mendes-Oliveira, A. C. (2014). The role of remnants of Amazon savanna for the conservation of Neotropical mammal communities in eucalyptus plantations. Biodiversity and Conservation, 23(13), 3171-3184. http://dx.doi.org/10 1007/s10531-014-0772-9.

Cullen, L., Jr, \& Bodmer, E. R. (2001). Ecological consequences of hunting in Atlantic forest patches, São Paulo, Brazil. Oryx, 35(2), 137-144. http://dx.doi.org/10.1046/j. 1365-3008.2001.00163.x.

Daily, G. C., Ceballos, G., Pacheco, J., Suzán, G., \& Sánchez-Azofeifa, A. (2003). Countryside biogeography of neotropical mammals: Conservation opportunities in agricultural landscapes of costa rica. Conservation Biology, 17(6), 1814-1826. http:// dx.doi.org/10.1111/j.1523-1739.2003.00298.x.

Díaz, S., Purvis, A., Cornelissen, J. H. C., Mace, G. M., Donoghue, M. J., Ewers, R. M., .. Pearse, W. D. (2013). Functional traits, the phylogeny of function, and ecosystem service vulnerability. Ecology and Evolution, 3(9), 2958-2975. http://dx.doi.org/10. 1002/ece3.601.

Dormann, C. F., Elith, J., Bacher, S., Buchmann, C., Carl, G., Carré, G., ... Lautenbach, S. (2013). Collinearity: A review of methods to deal with it and a simulation study evaluating their performance. Ecography, 36(1), 27-46. http://dx.doi.org/10.1111/j 1600-0587.2012.07348.x.

Dotta, G., \& Verdade, L. M. (2011). Medium to large-sized mammals in agricultural landscapes of south-eastern Brazil. Mammalia, 75(4), 345-352. http://dx.doi.org/10. 1515/MAMM.2011.049.

Edwards, D. P., Gilroy, J. J., Woodcock, P., Edwards, F. A., Larsen, T. H., Andrews, D. J. R., ... Wilcove, D. S. (2014). Land-sharing versus land-sparing logging: reconciling timber extraction with biodiversity conservation. Global Change Biology, 20, 183-191. http://dx.doi.org/10.1111/gcb.12353.

Ewers, R. M., \& Didham, R. K. (2006). Confounding factors in the detection of species responses to habitat fragmentation. Biological Reviews of the Cambridge Philosophical Society, 81(1), 117-142. http://dx.doi.org/10.1017/S1464793105006949.

FAO (2015). Global forest resources assessment 2015 desk reference. Rome: Food and Agriculture Organization of the United Nations.

Ferraz, S. F. B., Ferraz, K. M. P. M. B., Cassiano, C. C., Brancalion, P. H. S., da Luz, D. T.a, Azevedo, T. N., ... Metzger, J. P. (2014). How good are tropical forest patches for ecosystem services provisioning? Landscape Ecology, 29(2), 187-200. http://dx.doi. org/10.1007/s10980-014-9988-z.

Fischer, J., Lindenmayer, D. B., \& Manning, A. D. (2006). Biodiversity, ecosystem function, and resilience: Ten guiding principles for commodity production landscapes. Frontiers in Ecology and the Environment, 4(2), 80-86. http://dx.doi.org/10.1890/ 1540-9295(2006)004[0080:BEFART]2.0.CO;2.

Fischer, J., Abson, D. J., Butsic, V., Chappell, M. J., Ekroos, J., Hanspach, ... von Wehrden, H. (2014). Land sparing versus land sharing: Moving foward. Conservation Letters, 7(3), 149-157. http://dx.doi.org/10.1111/conl.12084.

Flynn, D. F. B., Gogol-Prokurat, M., Nogeire, T., Molinari, N., Richers, B. T., Lin, B. B., .. DeClerck, F. (2009). Loss of functional diversity under land use intensification across multiple taxa. Ecology Letters, 12(1), 22-33. http://dx.doi.org/10.1111/j.1461-0248. 2008.01255.x.

Foley, J. A., Defries, R., Asner, G. P., Barford, C., Bonan, G., Carpenter, S. R., ... Snyder, P. K. (2005). Global consequences of land use. Science (New York, N.Y.), 309(5734), 570-574. http://dx.doi.org/10.1126/science.1111772.

Fonseca, C. R., Ganade, G., Baldisera, R., Becker, C. G., Boelter, C. R., Brescovit, A. D., .. Vieira, E. M. (2009). Towards an ecologically-sustainable forestry in the Atlantic forest. Biological Conservation, 142, 1209-1219. http://dx.doi.org/10.1016/j.biocon. 2009.02.017.

Freitas, C. H., Setz, E. Z. F., Araújo, A. R. B., \& Gobbi, N. (2008). Agricultural crops in the diet of bearded capuchin monkeys, Cebus libidinosus Spix (Primates: Cebidae), in forest fragments in southeast Brazil. Revista Brasileira de Zoologia, 25(1), 32-39. http://dx.doi.org/10.1590/S0101-81752008000100006.

Galetti, M., Pardini, R., Barbanti Duarte, J. M., Ferreira da Silva, V. M., Rossi, A., Peres, C. A., ... Silva, V. M. F. (2010). Forest legislative changes and their impacts on mammal ecology and diversity in Brazil. Biota Neotropica, 10(4), 47-52.

Gardner, T. A., Barlow, J., Chazdon, R., Ewers, R. M., Harvey, Ca., Peres, Ca., ... Sodhi, N. S. (2009). Prospects for tropical forest biodiversity in a human-modified world. Ecology Letters, 12(6), 561-582. http://dx.doi.org/10.1111/j.1461-0248.2009. 01294.x.

Harcourt, A. H., \& Schwartz, M. W. (2001). Primate evolution: A biology of Holocene extinction and survival on the southeast Asian Sunda Shelf islands. American Journal of Physical Anthropology, 114(1), 4-17. http://dx.doi.org/10.1002/10968644(200101)114:18lt; 4::AID-AJPA1001\&ot:3.0.CO·2-6.

Hartley, M. (2002). Rationale and methods for conservating biodiversity in plantation forests. Forest Ecology and Management, 155, 81-95.

Hoffmann, M., Hilton-Taylor, C., Angulo, A., Böhm, M., Brooks, T. M., Butchart, S. H. M., ... Stuart, S. N. (2010). The impact of conservation on the status of the world's vertebrates. Science (New York, N.Y.), 330(6010), 1503-1509. http://dx.doi.org/10. 1126 /science.1194442.

Holliday, R. (2005). Ageing and the extinction of large animals. Biogerontology, 6(2),
151-156. http://dx.doi.org/10.1007/s10522-005-3458-6.

Hooper, D. U., Chapin, F. S., Ewel, J. J., Hector, A., Inchausti, P., Lavorel, S., ... Wardle, D. A. (2005). Effects of biodiversity on ecosystem functioning: A consensus of current knowledge. Ecological Monographs, 75(1), 3-35. http://dx.doi.org/10.1890/04-0922. Jones, K. E., Purvis, A., \& Gittleman, J. L. (2003). Biological correlates of extinction risk in bats. The American Naturalist, 161(4), 601-614. http://dx.doi.org/10.1086/368289.

Jorge, M. L. S. P., Galetti, M., Ribeiro, M. C., \& Ferraz, K. M. P. M. B. (2013). Mammal defaunation as surrogate of trophic cascades in a biodiversity hotspot. Biological Conservation, 163, 49-57. http://dx.doi.org/10.1016/j.biocon.2013.04.018.

Laliberté, E., \& Legendre, P. (2010). A distance-based framework for measuring functional diversity from multiple traits. Ecology, 91(1), 299-305. http://dx.doi.org/10. 1890/08-2244.1.

Lande, R. (1993). Risks of population extinction from demographic and environmental stochasticity and random catastrophes. The American Naturalist, 142(6), 911-927 Retrieved from http://www.jstor.org/stable/2462690.

Legendre, P., \& Legendre, L. (1998). Numerical ecology (2nd edition). Amsterdam: Elsevier Science B.V.

Legendre, P., \& Anderson, M. J. (1999). Distance-based redundancy analysis: Testing multispecies responses in multifactorial ecological experiments. Ecological Monographs, 69(1), 1-24. http://dx.doi.org/10.1890/0012-9615(1999) 069[0001:DBRATM]2.0.CO;2.

Legendre, P., Oksanen, J., \& ter Braak, C. J. F. (2011). Testing the significance of canonical axes in redundancy analysis. Methods in Ecology and Evolution, 2(3), 269-277. http://dx.doi.org/10.1111/j.2041-210X.2010.00078.x.

Lindenmayer, D. B., Cunningham, R. B., Donnelly, C. F., \& Lesslie, R. (2002). On the use of landscape surrogates as ecological indicators in fragmented forests. Forest Ecology and Management, 159(3), 203-216. http://dx.doi.org/10.1016/S0378-1127(01) 00433-9.

Lindenmayer, D. B., \& Hobbs, R. J. (2004). Fauna conservation in Australian plantation forests - A review. Biological Conservation, 119(2), 151-168. http://dx.doi.org/10. 1016/j.biocon.2003.10.028.

Lindenmayer, D. B., Hobbs, R. J., Montague-Drake, R., Alexandra, J., Bennett, A., Burgman, M., ... Zavaleta, E. (2008). A checklist for ecological management of landscapes for conservation. Ecology Letters, 11(1), 78-91. http://dx.doi.org/10. 1111/j.1461-0248.2007.01114.x.

Lyra-Jorge, M. C., Ciocheti, G., \& Pivello, V. R. (2008). Carnivore mammals in a fragmented landscape in northeast of São Paulo State, Brazil. Biodiversity and Conservation, 17(7), 1573-1580. http://dx.doi.org/10.1007/s10531-008-9366-8.

Marsden, S. J., Whiffin, M., \& Galetti, M. (2001). Bird diversity and abundance in forest fragments and Eucalyptus plantations around an Atlantic forest reserve, Brazil. Biodiversity and Conservation, 10(5), 737-751. http://dx.doi.org/10.1023/ A:1016669118956.

Martin, P. S., Gheler-Costa, C., Lopes, P. C., Rosalino, L. M., \& Verdade, L. M. (2012). Terrestrial non-volant small mammals in agro-silvicultural landscapes of Southeastern Brazil. Forest Ecology and Management, 282, 185-195. http://dx.doi. org/10.1016/j.foreco.2012.07.002.

Martinelli, L. A., Joly, C. A., Nobre, C. A., \& Sparovek, G. (2010). The false dicotomy between preservation of the natural vegetation and food production in Brazil. Biota Neotropica, 10(4), 323-330.

Mason, N. W. H., Mouillot, D., Lee, W. G., \& Wilson, J. B. (2005). Functional richness, functional and functional evenness divergence: The primary of functional components diversity. Oikos, 111(1), 112-118.

Mazerolle, M. J., \& Villard, M.-A. (1999). Patch characteristics and landscape context as predictors of species presence and abundance: A review. Ecoscience, 6(1), 117-124 Retrieved from http://www.jstor.org/stable/42901108.

McGarigal, K., Cushman, S. A., \& Enen, E. (2012). FRAGSTATS v4: spatial pattern analysis program for categorical and continuous maps. Amherst: Computer software program produced by the authors at the University of Massachusetts Retrieved from http:// www.umass.edu/landeco/research/fragstats/fragstats.html.

Mendonça, L. S. (2009). Os médios e grandes mamíferos de mosaicos em áreas de reflorestamentos no Centro-Oeste paulista. Universidade Estadual de Campinas.

Mikich, S. B., \& Liebsch, D. (2014). Damage to forest plantations by tufted capuchins (Sapajus nigritus): Too many monkeys or not enough fruits? Forest Ecology and Management, 314, 9-16. http://dx.doi.org/10.1016/j.foreco.2013.11.026.

Mouchet, M. A., Villéger, S., Mason, N. W. H., \& Mouillot, D. (2010). Functional diversity measures: An overview of their redundancy and their ability to discriminate community assembly rules. Functional Ecology, 24(4), 867-876. http://dx.doi.org/10. 1111/j.1365-2435.2010.01695.x.

Paglia, A. P., Fonseca, G. A. B., da, Rylands, A. B., Herrmann, G., Aguiar, L. M. S. Chiarello, A. G., ... Patton, J. L. (2012). Annotated checklist of Brazilian mammals $2^{\circ}$ Edição. Occasional Papers in Conservation Biology, 6, 1-76 Retrieved from http:// www.conservation.org/global/brasil/publicacoes/Documents/annotated_checklist_of_brazilian_mammals_2nd_edition.pdf.

Pedrosa, F., Salerno, R., Padilha, F. V. B., \& Galetti, M. (2015). Current distribution of invasive feral pigs in Brazil: economic impacts and ecological uncertainty. Natureza \& Conservação, 13(1), 84-87. http://dx.doi.org/10.1016/j.ncon.2015.04.005.

Pereira, H. M., \& Daily, G. C. (2006). Modeling biodiversity dynamics in countryside landscapes. Ecology, 87(8), 1877-1885. http://dx.doi.org/10.1890/0012-9658(2006) 87[1877:MBDICL]2.0.CO;2.

Peres-Neto, P. R., Legendre, P., Dray, S., \& Borcard, D. (2006). Variation partitioning of species data matrices: Estimation and comparison of fractions. Ecology, 87(10), 2614-2625.

Peres, C. A., Barlow, J., \& Haugaasen, T. (2003). Vertebrate responses to surface wildfires in a central Amazonian forest. Oryx, 37(1), 97-109. http://dx.doi.org/10.1017/ S0030605303000188.

Pimm, S. L., Jenkins, C. N., Abell, R., Brooks, T. M., Gittleman, J. L., Joppa, L. N., ... 
Sexton, J. O. (2014). The biodiversity of species and their rates of extinction, distribution, and protection. Science, 344(6187), 1246752. http://dx.doi.org/10.1126/ science. 1246752 .

Puker, A., Ad'Vincula, H. L., Korasaki, V., Ferreira, F. N. F., \& Orozco, J. (2014). Biodiversity of Cetoniinae beetles (Coleoptera: Scarabaeidae) in introduced and native habitats in the Brazilian Atlantic forest. Entomological Science, 17(3), 309-315. http://dx.doi.org/10.1111/ens.12069.

Purvis, A., Agapow, P.-M., Gittleman, J. L., \& Mace, G. M. (2000). Nonrandom extinction and the loss of evolutionary history. Science(April), http://dx.doi.org/10.1126/ science.288.5464.328.

Purvis, A., Gittleman, J. L., Cowlishaw, G., \& Mace, G. M. (2000). Predicting extinction risk in declining species. Proceedings. Biological Sciences / The Royal Society, 267(1456), 1947-1952. http://dx.doi.org/10.1098/rspb.2000.1234.

R Development Core Team (2014). R: A language and environment for statistical computing. Vienna: R Foundation for Statistical Computing.

Ramírez, P. A., \& Simonetti, J. A. (2011). Conservation opportunities in commercial plantations: The case of mammals. Journal for Nature Conservation, 19, 351-355. http://dx.doi.org/10.1016/j.jnc.2011.06.003.

Ribeiro, M. C., Metzger, J. P., Martensen, A. C., Ponzoni, F. J., \& Hirota, M. M. (2009) The Brazilian atlantic forest: How much is left, and how is the remaining forest distributed? Implications for conservation. Biological Conservation, 142(6), 1141-1153. http://dx.doi.org/10.1016/j.biocon.2009.02.021

Rocha, P. L. B.da, Viana, B. F., Cardoso, M. Z., de Melo, A. M. C., Costa, M. G. C., de Vasconcelos, R. N., ... Dantas, T. B. (2013). What is the value of eucalyptus monocultures for the biodiversity of the Atlantic forest? A multitaxa study in southern Bahia, Brazil. Journal of Forestry Research, 24(2), 263-272. http://dx.doi.org/10. 1007/s11676-012-0311-z.

Silva, C. R.de (2001). Riqueza e diversidade de mamíferos não-voadores em um mosaico formado por plantios de Eucalyptus saligna e remanescentes de Floresta Atlântica no município de Pilar do Sul, SP. Universidade de São Paulo.

Silveira, P. B.da (2005). Mamíferos de médio e grande porte em florestas de Eucalyptus spp com diferentes densidades de sub-bosque no município de Itatinga, SP. Universidade de São Paulo.

Spínola, C. M. (2008). Influência dos padrões estruturais da paisagem na comunidade de mamíferos terrestres de médio e grande porte na Região do Vale do Ribeira, Estado de São Paulo. Universidade de São Paulo.

Stallings, J. R. (1991). The importance of understorey on wildlife in a Brazilian eucalypt plantation. Revista Brasileira de Zoologia, 7(3), 267-276.

Suguituru, S. S., Silva, R. R., Souza, D. R., Munhae, C.de B., \& Morini, M. S.de C. (2011). Ant community richness and composition across a gradient from Eucalyptus plantations to secondary Atlantic Forest. Biota Neotropica, 11(1), 369-376. http://dx.doi.
org/10.1590/S1676-06032011000100034.

Ter Braak, C. J. F. (1994). Canonical community ordination. Part I: Basic theory and linear methods. Ecoscience, 1(2), 127-140.

Ter Braak, C. J. F., \& Prentice, I. C. (1988). A theory of gradient analysis. Advances in Ecological Research, 18(C), 271-317. http://dx.doi.org/10.1016/S0065-2504(08) 60183-X.

Thornton, D. H., Branch, L. C., \& Sunquist, M. E. (2011). The influence of landscape, patch, and within-patch factors on species presence and abundance: A review of focal patch studies. Landscape Ecology, 26(1), 7-18. http://dx.doi.org/10.1007/s10980010-9549-z.

Tscharntke, T., Tylianakis, J. M., Rand, T. A., Didham, R. K., Fahrig, L., Batáry, P., ... Westphal, C. (2012). Landscape moderation of biodiversity patterns and processes Eight hypotheses. Biological Reviews, 87(3), 661-685. http://dx.doi.org/10.1111/j. 1469-185X.2011.00216.x.

Umetsu, F., Metzger, J. P., \& Pardini, R. (2008). Importance of estimating matrix quality for modeling species distribution in complex tropical landscapes: A test with Atlantic forest small mammals. Ecography, 31(3), 359-370. http://dx.doi.org/10.1111/j. 0906-7590.2008.05302.x.

Vandermeer, J., \& Carvajal, R. (2001). Metapopulation dynamics and the quality of the matrix. The American Naturalist, 158(3), 211-220. http://dx.doi.org/10.1086/ 321318.

Vetter, D., Hansbauer, M. M., Végvári, Z., \& Storch, I. (2011). Predictors of forest fragmentation sensitivity in Neotropical vertebrates: A quantitative review. Ecography, 34(1), 1-8. http://dx.doi.org/10.1111/j.1600-0587.2010.06453.x.

Villéger, S., Mason, N. W. H., \& Mouillot, D. (2008). New multidimensional functional diversity indices for a multifaceted framework in functional ecology. Ecology, 89(8), 2290-2301. http://dx.doi.org/10.1890/07-1206.1.

Volpato, G. H., Prado, V. M., \& dos Anjos, L. (2010). What can tree plantations do for forest birds in fragmented forest landscapes? A case study in southern Brazil. Forest Ecology and Management, 260(7), 1156-1163. http://dx.doi.org/10.1016/j.foreco. 2010.07.006.

Yue, S., Brodie, J. F., Zipkin, E. F., \& Bernard, H. (2015). Oil palm plantations fail to support mammal diversity. Ecological Applications, 25(8), 2285-2292. http://dx.doi. org/10.1890/14-1928.1.

Zhang, M., Chang, C., \& Quan, R. (2017). Natural forest at landscape scale is most important for bird conservation in rubber plantation. Biological Conservation, 210, 243-252. http://dx.doi.org/10.1016/j.biocon.2017.04.026.

Zurita, G. A., Rey, N., Varela, D. M., Villagra, M., \& Bellocq, M. I. (2006). Conversion of the Atlantic Forest into native and exotic tree plantations: Effects on bird communities from the local and regional perspectives. Forest Ecology and Management, 235(1-3), 164-173. http://dx.doi.org/10.1016/j.foreco.2006.08.009. 